\title{
Hepatic Amyloidosis - When Looks are Deceptive!
}

Mukul Rastogi ${ }^{1}$, Nalini Bansal ${ }^{2^{\star}}$, Min Aung Shan ${ }^{3}$ and Vivek $\mathrm{Vij}^{4}$

${ }^{1}$ Department of Hepatology, Fortis Hospital, Noida, India

${ }^{2}$ Department of Hepatology, SRL Ltd, Fortis Hosital, New Delhi, India

${ }^{3}$ Department of Hepatology, Defence Services Liver Hospital, Myanmar

${ }^{4}$ Director Liver Transplant Surgery, Fortis Hospital, Noida, India

*Corresponding author: Bansal N, Senior Histopathologist, SRL Ltd, Fortis Hosital New Delhi, India, Tel: 9990370677; E-mail: drnalinibansal@yahoo.com Received date: August 14, 2018; Accepted date: August 29, 2018; Published date: August 31, 2018

Copyright: ( 2018 Rastogi M, et al. This is an open-access article distributed under the terms of the Creative Commons Attribution License, which permits unrestricted use, distribution, and reproduction in any medium, provided the original author and source are credited.

\section{Abstract}

The liver can be involved in many systemic diseases, including infectious, immunologic, metabolic, vascular, infiltrative, and neoplastic diseases. Amyloidosis is a rare systemic disorder characterized by the deposition of insoluble, fibril-forming amyloid proteins in the extracellular space of various organs and it is more frequently observed in the gastrointestinal tract, heart and kidney. Liver can also be involved but often remain clinically silent with abnormal liver function tests and organ enlargement. The clinical and imaging features of the disease are often nonspecific and a tissue biopsy is often required. Hepatic involvement of the systemic amyloidosis is usually presented as diffuse infiltration and hepatomegaly, but very rarely may appear as unusual focal mass. Hepatic dysfunction is usually subclinical, however, in some patients, there is massive involvement of the liver could lead to acute liver failure, acute on chronic liver failure and decompensated cirrhosis of liver. We present the two rare cases of hepatic involvement of systemic amyloidosis. First case is of primary AL-systemic amyloidosis that presented as hepatic lesions, in the setting of plasma cell dyscrasia. Second case is of secondary AA-systemic amyloidosis that presented as decompensated chronic liver disease reported first time in literature which required liver transplantation.
\end{abstract}

Keywords: Amyloidosis; Hepatic lesions; Decompensated chronic liver disease; Liver transplantation

\section{Introduction}

Systemic amyloidosis is a rare disease characterized by the deposition of various insoluble, fibril-forming amyloid proteins in the extracellular matrix and vessel walls of any organs in the form of a focal, tumour-like lesion, or an infiltrative process [1]. The global incidence of amyloidosis is estimated at five to nine cases per million patient-years. The main subtypes of systemic amyloidosis are primary AL amyloidosis, secondary amyloid A (AA) amyloidosis, familial amyloidosis, and $B 2$-microglobulin-related amyloidosis [2]. Systemic AA amyloidosis is the most common type of amyloidosis worldwide, and reported as more frequent in developed countries, associated with underlying chronic infections. Systemic AL amyloidosis is the most common type in some European regions and in developing countries [3]. In primary amyloidosis, abnormal serum immunoglobulin AL ( $\kappa$ or $\lambda$ light chain) deposited in target organs and it results from multiple myeloma, other immunocyte dyscrasias and malignant B-cell-type lymphoproliferative malignancies. In secondary amyloidosis, abnormal serum amyloid A (AA) deposited in target organs and it results from chronic inflammation, immunological disorders, and neoplastic diseases [4]. Amyloidosis is particularly difficult to diagnose because the signs and symptoms are subtle. Even when suspected clinically and radiologically, the diagnosis of amyloidosis depends on a tissue biopsy for histological evidence of amyloid deposits and deposition of amyloid subtype [5].

In both primary and secondary systemic amyloidosis, the most commonly involved organ system is the gastrointestinal system, with the colon being the most common site [1]. Earlier descriptions suggest that systemic primary AL amyloidosis mainly involves tongue, heart, gut, muscle nerve and skin, whereas secondary amyloidosis involves liver, spleen, kidney and adrenals predominantly [3]. Hepatic involvement is more common in secondary systemic AA-amyloidosis as diffuse infiltration, but liver involvement in primary systemic ALamyloidosis is uncommon [5]. The presentation of hepatic involvement of systemic amyloidosis often remains clinically silent except for deranged liver function tests and hepatomegaly but very rarely may appear as unusual focal mass [6-8] and in some patients with massive involvement of the liver presenting as acute liver failure, acute on chronic liver failure and decompensated cirrhosis of liver.

Here we report two rare cases of hepatic involvement of systemic amyloidosis.

\section{Case Report}

\section{Primary systemic amyloidosis as hepatic lesions: A case report 1}

A 58-year-old female patient who had diabetes mellitus and was hypothyroid presented with vague abdominal discomfort and significant weight loss of $25 \mathrm{~kg}$ over one year. On examination, she had huge hepatomegaly which was hard in consistency, with sharp margin, smooth surface, non-tender, without hepatic bruit.

On evaluation, haemogram revealed normocytic normochromic anemia with total white cell count 6.32 thou/uL (4-10 thou/uL) and platelets count of 328 thou/uL (150-410 thou/uL). Serum total bilirubin was $2.04 \mathrm{mg} / \mathrm{dl}(0.2-1.0 \mathrm{mg} / \mathrm{dl})$ with direct bilirubin of 1.52 
Citation: Rastogi M, Bansal N, Shan MA, Vij V (2018) Hepatic Amyloidosis - When Looks are Deceptive!. J Cytol Histol 9: 520. doi:

Page 2 of 5

$\mathrm{mg} / \mathrm{dl}(0.0-0.2 \mathrm{mg} / \mathrm{dl})$, aspartate aminotransferase was $61 \mathrm{U} / \mathrm{L}$ (15-37 $\mathrm{U} / \mathrm{L})$, alanine aminotransferase was $70 \mathrm{U} / \mathrm{L}(<34 \mathrm{U} / \mathrm{L})$, and alkaline phosphatase was $1195 \mathrm{U} / \mathrm{L}$ (30-120 U/L), gamma glutamyl transferase was $877 \mathrm{U} / \mathrm{L}$ (5-55 U/L). Serum total protein level was $6.8 \mathrm{~g} / \mathrm{dl}$ (6.4-8.2 $\mathrm{g} / \mathrm{dl})$ with serum albumin level of $3.4 \mathrm{~g} / \mathrm{dl}(3.4-5.0 \mathrm{~g} / \mathrm{dl})$. Alpha-feto protein was $2.57 \mathrm{ng} / \mathrm{ml}(<10 \mathrm{ng} / \mathrm{ml})$. Prothrombin time was $14.9 \mathrm{~s}$ with INR of 1.25 . Serum urea was $17 \mathrm{mg} / \mathrm{dl}(6-10 \mathrm{mg} / \mathrm{dl})$ with creatinine level of $0.76 \mathrm{mg} / \mathrm{dl}(0.6-1.1 \mathrm{mg} / \mathrm{dl})$.

Her TSH was $5.66 \mu \mathrm{IU} / \mathrm{mL}(0.27-4.2 \mathrm{uIU} / \mathrm{ml})$. Serum calcium was $10.6 \mathrm{mg} / \mathrm{dl}(8.5-10.1 \mathrm{mg} / \mathrm{dl})$, random blood sugar was $125 \mathrm{mg} / \mathrm{dl}$.
HBsAg, Anti-HCV and HIV antibody were negative. Serum IgG was normal and Anti-nuclear antibody was negative.

UGI endoscopy revealed small gastric polyp, hyperemia in fundus and body of the stomach. Biopsy showed chronic active gastritis and fundic gland polyps. Triple phase CT abdomen revealed gross hepatomegaly with portovenous enhancing nodule $(2.6 \times 1.7 \mathrm{~cm})$ seen in the segment III left lobe of liver and small non enhancing hypodense area $(0.8 \times 0.6 \mathrm{~cm})$ seen in the segment VII right lobe of liver (Figure 1).

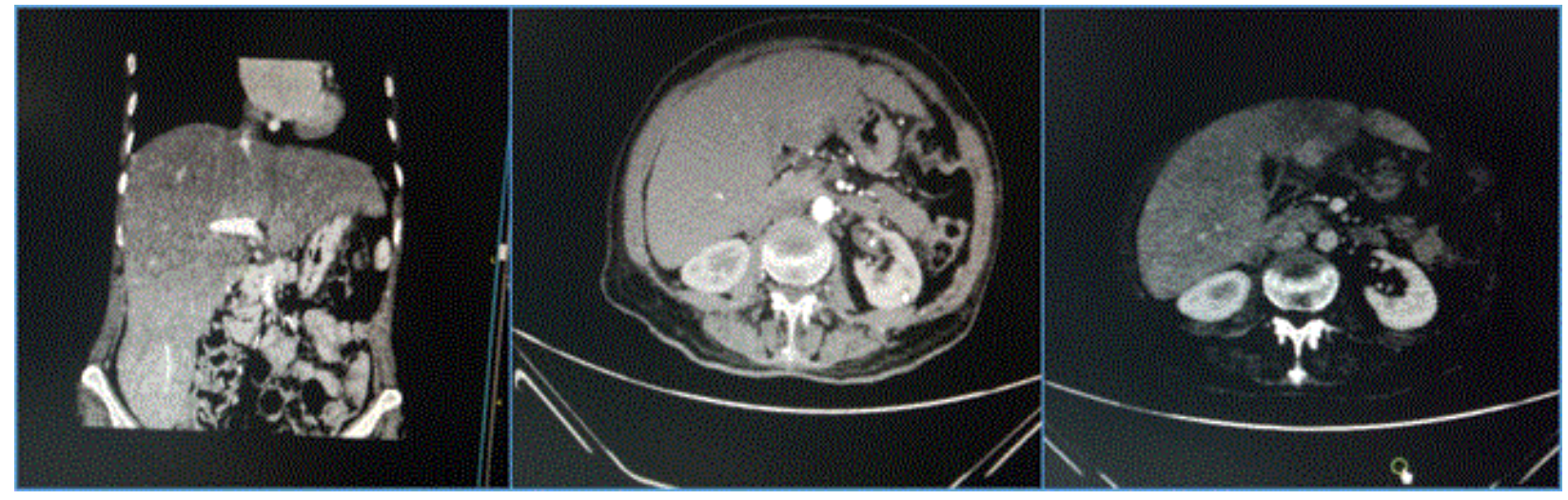

Figure 1: CECT showing revealed gross hepatomegaly with portovenous enhancing nodule $(2.6 \times 1.7 \mathrm{~cm})$ seen in the segment III left lobe of liver and small non enhancing hypodense area $(0.8 \times 0.6 \mathrm{~cm})$ seen in the segment VII right lobe of liver.

Liver biopsy showed deposition of eosinophilic cellular congophilic positive material in a sinusoidal pattern mainly within the space of disse (Figure 2a and 2c). These areas were Congo red stain positive with apple green birefringence on polarizing microscopy suggestive of Amyloid deposits (Figure $2 \mathrm{~b}$ and $2 \mathrm{~g}$ ). The deposits were weakly positive in PAS stain. Immunohistochemistry showed light chain restriction with predominance of kappa staining over lambda stain (Figure $2 \mathrm{~d}$ and $2 \mathrm{e}$ ). Immunohistochemistry using anti serum amyloid associated (SAA) protein immunoperoxidase staining for secondary amyloidosis was negative.

Serum protein electrophoresis examination showed hypogammaglobulinemia with myeloma band detected. On serum protein immunofixation electrophoresis showed kappa band detected with increased kappa free light chain assay of $675 \mathrm{mg} / \mathrm{L}$ (3.30-19.4 $\mathrm{mg} / \mathrm{L}$ ) and Kappa lambda ratio of 79.25 and serum Immunoglobulin (Ig) levels of IgA $0.58 \mathrm{~g} / \mathrm{L}(0.52-4.68 \mathrm{~g} / \mathrm{L}), \operatorname{IgG} 8.77 \mathrm{~g} / \mathrm{L}(6.5-16.4 \mathrm{~g} / \mathrm{L})$ and low IgM $0.27 \mathrm{~g} / \mathrm{L}(0.39-3.38 \mathrm{~g} / \mathrm{L})$. On urine protein reflex immunofixation electrophoresis revealed urine albumin, urine alpha 1 and beta were detected and there was no urinary bence-jones proteinuria. Bone marrow biopsy revealed few myeloid cells seen showing maturation till neutrophilic stage, mature plasma cells 9-10\% seen with suggestive of plasma cell dyscrasia. There was presence of amyloid deposits within the marrow with apple green birefringences. (Figure $2 \mathrm{f}$ and $2 \mathrm{~g}$ ) Skeletal survey showed no gross abnormalities. There was no evidence of cardiac, renal, gastrointestinal or nervous system involvement, tuberculosis, or evidence of other common inflammatory diseases.

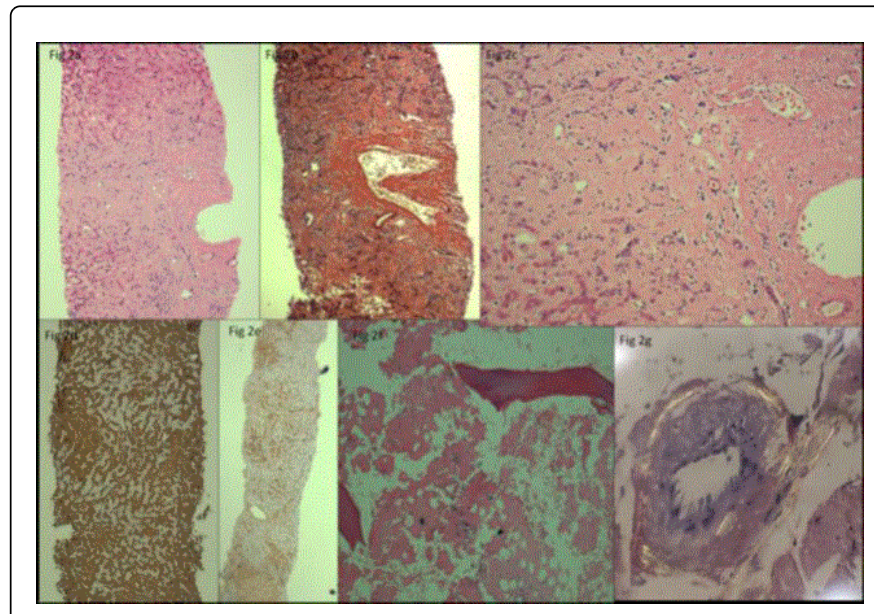

Figure 2: (a) Liver biopsy showing sinusoidal amyloid deposits (HE $10 \times$ ) (b) Congo red positive staining in amyloid (c) Predominant sinusoidal amyloid deposits (HE 40×) (d) IHC Kappa stain (e) IHC Lambda weakly staining (f) Bone biopsy showing amyloid deposits (g) Apple green birefringes on polarizer.

She was managed with systemic chemotherapy using IV Dexamethasone $40 \mathrm{mg}$ once a week, IV Bortezomib $2 \mathrm{mg}$ once a week, IV Zoledronic acid $4 \mathrm{mg}$ once in 3 months and Thalidomide $50 \mathrm{mg}$ PO daily. She responded well to systemic chemotherapy and is well after a year of regular follow up. 


\section{Secondary systemic amyloidosis as decompensated cirrhosis requiring liver transplantation: A case report 2}

A 47-year-old female, presented with abdominal swelling for 5 months duration. She had history of focal segmental glomerulonephritis, biopsy proven in 2008 for which she was treated with steroids. But she developed chronic kidney disease stage $\mathrm{V}$ requiring regular haemodialysis since May 2014. She was also found to have HCV infection in Jan 2015 but HCV RNA was negative. USG (abdomen) showed cirrhosis of liver and transjugular liver biopsy revealed features of fibrosis at that time. She developed ascites and ascitic tapping had been done twice. There was no history of GI bleeding, SBP, HRS and hepatic encephalopathy.

On examination, moderate was ascites present. On evaluation, haemogram revealed hypochromic normocytic anemia with total white cell count $6.9(4-10$ thou/uL) and platelet level of 166 thou/uL (150-410 thou/uL). Liver biochemistry showed total bilirubin level of $0.58 \mathrm{mg} / \mathrm{dl}(0.2-1.0 \mathrm{mg} / \mathrm{dl})$ with direct bilirubin $0.26 \mathrm{mg} / \mathrm{dl}(0.0-0.2$ $\mathrm{mg} / \mathrm{dl})$, aspartate aminotransferase level of $84 \mathrm{U} / \mathrm{L}$ (15-37 U/L), alanine aminotransferase level of $34 \mathrm{U} / \mathrm{L}(<34 \mathrm{U} / \mathrm{L})$, and alkaline phosphatase value of $239 \mathrm{U} / \mathrm{L}(30-120 \mathrm{U} / \mathrm{L})$, gamma glutamyl transferase value of $131 \mathrm{U} / \mathrm{L}$ (5-55 U/L). Serum total protein level was $8.7 \mathrm{~g} / \mathrm{dl}(6.4-8.2 \mathrm{~g} / \mathrm{dl})$ with serum albumin level of $3.6 \mathrm{~g} / \mathrm{dl}(3.4-5.0$ $\mathrm{g} / \mathrm{dl})$ (corrected). Alpha-feto protein was $1.79 \mathrm{ng} / \mathrm{ml}(<10 \mathrm{ng} / \mathrm{ml})$. Prothrombin time was $16.7 \mathrm{~s}$ with INR of 1.29 . Serum urea was 39 $\mathrm{mg} / \mathrm{dl}(6-10 \mathrm{mg} / \mathrm{dl})$ with creatinine level of $7.69 \mathrm{mg} / \mathrm{dl}(0.6-1.1 \mathrm{mg} / \mathrm{dl})$. Clinical albuminuria was present with urinary albumin creatinine ratio of 6941 .

HBsAg and HIV antibody were negative. Anti-HCV antibody was positive with HCV RNA level $<15 \mathrm{IU} / \mathrm{ml}$. Serum IgG was normal and Anti-nuclear antibody was negative. Her thyroid stimulating hormone was normal. Her serum calcium was $8.2 \mathrm{mg} / \mathrm{dl}(8.5-10.1 \mathrm{mg} / \mathrm{dl})$ and random blood sugar was $134 \mathrm{mg} / \mathrm{dl}$.

UGI enoscopy revealed no varies but mild portal-hypertensive gastropathy present. Triple phase CT abdomen showed features of chronic liver disease with mild splenomegaly and moderate ascites present, no intrahepatic lesions. Ascitic fluid analysis showed high SAAG 1.5 and high protein 4.6, no features of SBP. 2D Echo showed normal LVEF $60 \%$, moderate to severe TR, possibly due to fluid overload, secondary to chronic kidney disease and cirrhosis of liver.

She was diagnosed as decompensated cirrhosis of liver, Child-Pugh score 7 (B), MELD Na [9] and chronic kidney disease stage $\mathrm{V}$ after evaluation. Living donor combined liver and kidney transplantation was done on June 2016. Her explant liver histopathology revealed increased periportal fibrosis with formation of portal-portal bridges. There is deposition of prominent eosinophilic extracellular hyaline, acellular material in form of globules and linear deposition in perisinusoidal, portal venular and portal stromal regions (Figure 3a). The deposits were positive for Congo red stain. Immunohistochemistry using anti serum amyloid associated (SAA) protein immunoperoxidase staining for secondary amyloidosis was diffusely positive (Figure 3b-3d) and negative staining for kappa and lambda light chain. Explant liver showed secondary hepatic amyloidosis with chronic hepatitis and advance fibrosis and negative for malignancy. On further evaluation, there was no evidence of chronic infectious and non-infectious inflammatory diseases.

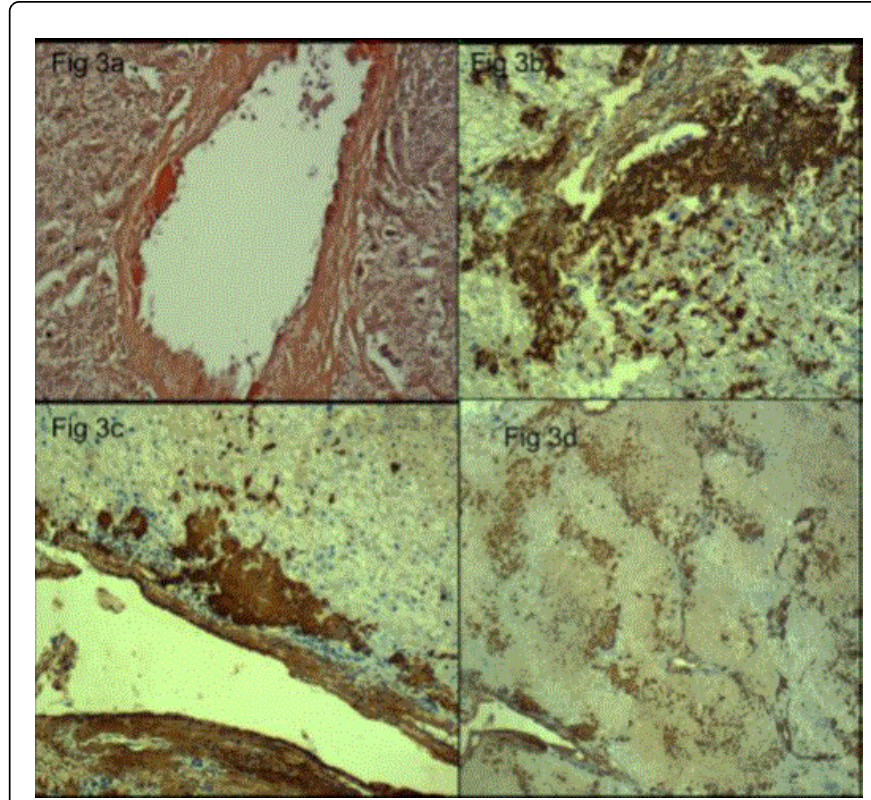

Figure 3: (a) Portal stromal and sinusoidal amyloid deposits (b-d) IHC SAA positive in amyloid deposits.

She was started tacrolimus and mycophenolate mofetil on postoperative day 1 . Liver function tests showed as total bilirubin level $0.47 \mathrm{mg} / \mathrm{dl}$, AST $61 \mathrm{U} / \mathrm{L}$, ALT $126 \mathrm{U} / \mathrm{L}$, ALP $127 \mathrm{U} / \mathrm{L}$, GGT $104 \mathrm{U} / \mathrm{L}$ and serum creatinine was $0.52 \mathrm{mg} / \mathrm{dl}$ on 3 weeks after transplantation. She responded well to immunosuppressive therapy and uneventful after, combined liver and kidney transplantation and is now on regular follow up.

\section{Discussion and Conclusion}

Amyloidosis is a heterogeneous group of diseases caused by the extracellular deposition of autologous fibrillar proteins, which aggregate into a three-dimensional ß-lamina disposition. These abnormal proteins are rapidly deposited and difficult to brake down, resulting in impairment of normal organ function [10]. Amyloidosis can be classified into various subtypes based on the nature and chemical composition of protein deposited. The main subtypes are primary AL amyloidosis, secondary amyloid A (AA) amyloidosis, familial amyloidosis, and ß2-microglobulin-related amyloidosis [11].

Primary amyloidosis is caused by deposition of immunoglobulin light chains (AL) in targeted organs and is usually seen in plasma cell dyscrasia with production of an abnormal light chain protein. Median survival time for patients with primary amyloidosis is 1.5 years (fiveyear survival of 17\%) [12-14]. Secondary amyloidosis is caused by deposition of protein serum amyloid A amyloid associated protein (AA) and is usually seen secondary to long standing chronic inflammatory diseases like chronic osteomyelitis, chronic infectious and non-infectious inflammatory conditions. Median survival time for patients with secondary amyloidosis is 4.5 years $[15,16]$. We present two cases, one of primary AL amyloidosis associated with plasma cell dyscrasia and other of secondary AA amyloidosis with undetermined cause.

The systemic amyloidosis is two times more common in males than in females and usually affects the patients in their 6th to 7 th decades, 
with a median age of diagnosis being 63-64 years [17]. In our cases, these two patients are females with 58 and 47 years of age. Amyloidosis is usually observed in a systemic form although $10-20 \%$ of cases are localized [18]. In both primary and secondary amyloidosis, the most commonly involved organ system is the gastrointestinal system, with the colon being the most common site [1]. Other studies showed that systemic amyloidosis involved in kidney (46\%), heart (30\%), liver (9\%), spleen (5-10\%), and gastrointestinal tract (7\%) [19]. In the present two cases, mainly liver involvement in both primary and secondary systemic amyloidosis.

The clinical manifestations of hepatic involvement are usually mild and frequently misdiagnosed. The most frequent findings in patients with hepatic amyloidosis are involuntary weight loss, hepatomegaly (81\%) and elevated serum alkaline phosphatase levels (86\%) [20]. Symptomatic involvement, including rupture, acute liver failure, acute on chronic liver failure, decompensated chronic liver disease, is rare $[21,22]$. In our cases, one presented as significant weight loss, hepatomegaly and cholestatic features and other presented as decompensated chronic liver disease.

Radiological findings of hepatic involvement are nonspecific with heterogeneous echogenicity on ultrasonography and none of the present imaging techniques is capable of specifically demonstrating the present of amyloidosis. In first case, one small portovenous enhancing nodule and one small non enhancing hypodense area were seen on triple phases CT abdomen with hepatomegaly. These may be the progressive deposition of the amyloid compress and the replacement of normal hepatocytes, the masses showed delayed contrast enhancement in the dynamic phase. In second case, findings were in favour of decompensated liver cirrhosis.

Diagnosis of amyloidosis is based on clinical organ involvement and histological evidence of amyloid deposits. Among the staining characteristics of amyloid deposits, rose pink positivity on Congo red and presence of apple green birefringes on a polarized light remain the gold standard. Further work up on histology includes immunohistochemical staining with kappa, lambda and SAA (Serum amyloid associated protein). Serological work up includes immunofixation and protein electrophoresis of the blood and urine, bone marrow biopsy, and other chronic inflammatory conditions. Hepatic involvement of AL-systemic amyloidosis is less commonly associated with myeloma (32\%) when compared with chronic leukemia (80-100\%), myeloproliferative diseases, acute leukemia (60-70\%), and non-Hodgkin lymphoma (50-60\%) [4]. In our first case, histologically primary light chain $(\mathrm{AL})$ types amyloidosis involving the liver associated with plasma cell dyscrasia.

Early diagnosis is a key for effective chemotherapy and allows the regression of the organ damage and avoids the progression to end stage organ dysfunction. All treatment options should be based upon a greater control of the underlying disease, adequate organ support, and treatment of symptoms. For amyloid light-chain (AL) amyloidosis, chemotherapy is the mainstay treatment to rapidly reduce the supply of misfolded amyloidogenic AL protein. The combination therapy with mephalan plus steroid has previously been described as a standard therapy for AL amyloidosis. Recently developed a proteasome inhibitor, bortezomib-based regimen has also been used for $\mathrm{AL}$ amyloidosis $[10,23]$. We treated the first case of primary hepatic AL amyloidosis, in the setting of plasma cell dyscrasia with bortezomibbased regimen which the patient tolerated well with no obvious significant side effects. Liver transplantation may represent a potential salvage treatment option for familial amyloidotic polyneuropathy
(FAP), hepatic amyloidosis with acute severe liver failure, acute on chronic liver failure. We performed combined liver and kidney transplantation in second case with decompensated cirrhosis of liver associated with chronic kidney disease stage $\mathrm{V}$ due to focal segmental glomerulonephritis. The case had been diagnosed as hepatic AA amyloidosis on explant liver histopathology.

In conclusion, hepatic amyloidosis should be considered as one of the causes of unexplained space occupying lesions in liver as well as in decompensated chronic liver disease with undetermined etiologies because it may very rarely appear as unusual focal masses and complicate to decompensated chronic liver disease. Hepatic tissue biopsy is necessary to get definite diagnosis. Further evaluation of the underlying association of plasma cell dyscrasia, myeloproliferative diseases and other chronic infectious or inflammatory diseases should be performed. Bortezomib-based regimen has shown promising activity and no significant toxicity for AL amyloidosis. Although the role of liver transplantation in the management of systemic amyloidosis is well established in the familial forms like familial amyloidotic polyneuropathy and transthyretin, liver transplantation should also be considered for acute or decompensated hepatic failure for hepatic amyloidosis.

\section{References}

1. Georgiades CS, Neyman EG, Barish MA, Fishman EK (2004) Amyloidosis: review and CT manifestations. Radiographics 24: 405-416.

2. Pepys MB (2006) Amyloidosis. Annu Rev Med 57: 223-241.

3. Pinney JH, Smith CJ, Taube JB (2013) Systemic amyloidosis in England: an epidemiological study. Br J Haematol 161: 525-532.

4. Kyle RA, Gertz MA (1995) Primary systemic amyloidosis: clinical and laboratory features in 474 cases. Semin Hematol 32: 45-59.

5. Gullu BE, Hatem I, Ozbay G, Tuzuner N, Sonsuz A (2011) A rare case of primary systemic amyloidosis presenting with hepatic failure. Turkish J Gastroenterol 22: 113-114.

6. Son RC, Chang JC, Choi JH (2011) Primary hepatic amyloidosis: report of an unusual case presenting as a mass. Korean J Radiol 12: 382-385.

7. Srinivasan S, Tan YQ, The HS, Lee PJ, Khoo RN (2014) Primary hepatic amyloidosis presenting as nodular masses on the background of diffuse infiltration and extreme liver stiffness on MR elastography. J Gastrointestin Liver Dis 23: 437-440.

8. Kiran S, Modi T, Shukla A, Bhatia S (2016) Primary systemic amyloidosis presenting as an intrahepatic space-occupying lesion. Tropical Gastroenterology 37: 216-218.

9. Kastritis E, Wechalekar AD, Dimopoulos MA (2010) Bortezomib with or without dexamethasone in primary systemic (light chain) amyloidosis. J Clin Oncol 28: 1031-1037.

10. Glenner GG (1980) Amyloid deposits and amyloidosis-The betafibrilloses (first of two parts). N Engl J Med 302: 1283-1292.

11. (1993) Nomenclature of amyloid and amyloidosis. WHO-IUIS Nomenclature Sub-Committee. Bull World Health Organ 71: 105-112.

12. Gertz MA, Kyle RA (2003) Amyloidosis with IgM monoclonal gammopathies. Semin Oncol 30: 325-328.

13. Joss N, McLaughlin K, Simpson K, Boulton-Jones JM (2000) Presentation, survival and prognostic markers in AA amyloidosis. Qjm 93: 535-542.

14. Pasqualetti P, Casale R (1997) Risk of malignant transformation in patients with monoclonal gammopathy of undetermined significance. Biomed Pharmacother 51: 74-78.

15. Maniatis A (1998) Pathophysiology of paraprotein production. Ren Fail 20: 821-828.

16. Dhodapkar MV, Merlini G, Solomon A (1997) Biology and therapy of immunoglobulin deposition diseases. Hematol Oncol Clin North Am 11: 89-110. 
Citation: Rastogi M, Bansal N, Shan MA, Vij V (2018) Hepatic Amyloidosis - When Looks are Deceptive!. J Cytol Histol 9: 520. doi: 10.4172/2157-7099.1000520

Page 5 of 5

17. Cohen Ad, Comenzo RL (2010) Systemic light-chain amyloidosis: advances in diagnosis, prognosis and therapy. Hematology AM Soc Hemato Educ Program 2010: 287-294.

18. Scott PP, Scott WW, Siegelman SS (1986) Amyloidosis: an overview. Semin Roentgenol 21: 103-112.

19. Merlini G, Bellotti V (2003) Molecular mechanisms of amyloidosis. N Eng J Med 349: 583-596.

20. Kim SH, Han JK, Lee KH, Won HJ, Kim KW, et al. (2003) Abdominal amyloidosis: spectrum of radiological findings. Clin Radiol 58: 610-620.
21. Gertz MA, Kyle RA (1997) Hepatic amyloidosis: clinical appraisal in 77 patients. Hepatology 25: 118-121.

22. Monzawa S, Tsukamoto T, Omata K, Hosoda K, Araki T, et al. (2002) A case with primary amyloidosis of the liver and spleen: radiologic findings. Eur J Radiol 41: 237-241.

23. Lamm W, Willenbacher W, Lang A (2011) Efficacy of the combination of bortezomib and dexamethasone in systemic AL amyloidosis. Ann Hematol 90: 201-206. 